\title{
WINTER HABITAT SELECTION PATTERNS OF MERRIAM'S TURKEYS IN THE SOUTHERN BLACK HILLS, SOUTH DAKOTA
}

\author{
Chad P. Lehman ${ }^{1,3}$, Mark A. Rumble ${ }^{2}$, and Lester D. Flake ${ }^{1}$
}

\begin{abstract}
In northern areas of their expanded range, information on Merriam's turkeys (Meleagris gallopavo merriami) is lacking, specifically pertaining to wintering behavior and factors associated with winter habitat selection. Forest managers need detailed quantification of the effects of logging and other management practices on wintering habitats needed by Wild Turkeys and other wildlife. Therefore, we examined winter habitat selection patterns within ponderosa pine (Pinus ponderosa) forests and determined factors associated with use of farmsteads by Merriam's turkeys in the southern Black Hills, South Dakota. We radio-marked 86 female Merriam's turkeys (70 adults and 16 yearlings) and monitored them during winter (1 December-31 March), 2001-2004. Female Wild Turkeys used recently burned pine forest less than expected but selected farmsteads and stands of mature ponderosa pine $(<70 \%$ overstory canopy cover, $>22.9 \mathrm{~cm}$ diameter at breast height $[\mathrm{DBH}]$ trees) for foraging sites. Within forests, female Wild Turkeys selected foraging sites with less understory vegetation and visual obstruction, and larger-diameter ponderosa pine. Ponderosa pine seed abundance varied among years, and pine seeds were most abundant in stands of 30-35 cm DBH with basal area of 22-28 $\mathrm{m}^{2} \cdot \mathrm{ha}^{-1}$. Abundance of pine seeds may have influenced use of farmsteads by Wild Turkeys, more so than ambient temperatures or snow depth. In the southern Black Hills, management should emphasize open- to mid-canopy and mature-structural-stage pine stands, where seed production was greatest. During winters when mast from pine is unavailable, farmsteads likely provide nutritional supplementation and may be important for maintaining Merriam's turkey populations.
\end{abstract}

Key words: Wild Turkey, Meleagris gallopavo merriami, Merriam's turkey, habitat, selection, ponderosa pine, farmstead, Black Hills, South Dakota.

To nest successfully, female Wild Turkeys (Meleagris gallopavo) rely on endogenous energy reserves they obtain during winter and early spring (Porter et al. 1983, Vander Haegen et al. 1988). During winter, Merriam's turkeys (M. g. merriami) in northern ranges often forage on natural foods such as ponderosa pine (Pinus ponderosa) seeds (Rumble and Anderson 1996a) or waste grains obtained from farmsteads (Hengel 1990, Hoffman et al. 1996). Egg production is reduced if turkey diets are deficient in protein (Gardner and Arner 1968), and turkeys may shift their patterns of habitat use to obtain adequate nutrition for survival and reproduction. For example, Merriam's turkeys in the central Black Hills selected dense ponderosa pine forest on southerly exposures in years of good seed production, and they consumed mostly pine seeds (Rumble and Anderson 1996a). However, in years of poor pine seed production, Wild Turkeys selected forest openings (Hoffman et al. 1993) or open pine stands and shifted their diets to bearberry (Arctostaphylos uva-ursi) seeds and grass seeds (Rumble and Anderson 1996a, 1996b).

Research has demonstrated nonrandom selection of habitats at multiple scales in the Black Hills (Rumble and Anderson 1992, 1996c). However, selection of microsites by Wild Turkeys within particular forest structural stages has not been investigated and would be useful information for forest and wildlife managers. Understanding these habitat characteristics provides insight into the ultimate factors that may describe Wild Turkey habitat selection. Additionally, factors influencing farmstead selection have not been investigated in the northern latitudes of the Merriam's turkey range. Consequently, our study objectives were to (1) estimate Merriam's turkey winter habitat selection at macro- (3rd-order) and microhabitat levels (4thorder; Johnson 1980) across all structural-stage categories, (2) examine patterns of microhabitat selection within major forest structural-stage

\footnotetext{
${ }^{1}$ Department of Wildlife and Fisheries Sciences, South Dakota State University, Brookings, SD 57007-1696.

${ }^{2}$ USDA Forest Service, Rocky Mountain Research Station, 8221 South Highway 16, Rapid City, SD 57702.

${ }^{3}$ Present address: Custer State Park, 13329 U.S. Hwy. 16A, Custer, SD 57730.
} 


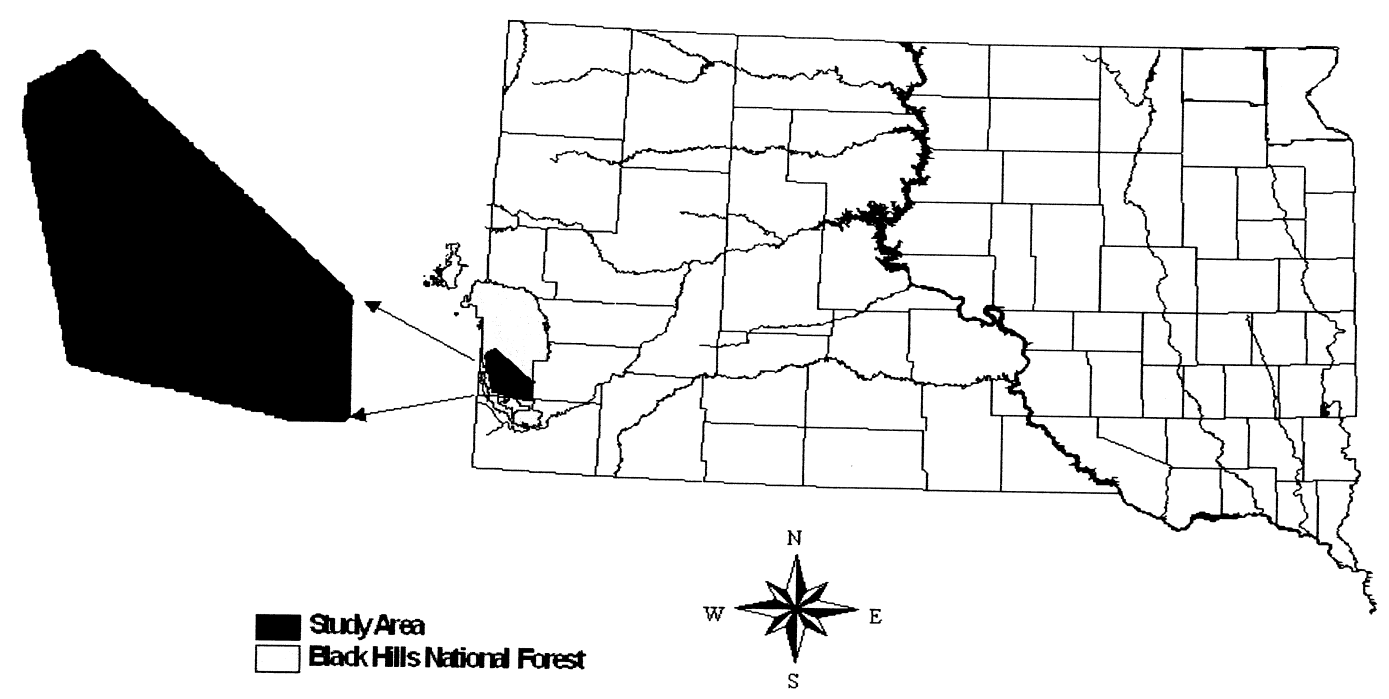

Fig. 1. Location of study area in Custer and Fall River Counties in the southern Black Hills, South Dakota, 2001-2004.

categories, and (3) identify environmental factors associated with selection of farmsteads by Wild Turkeys.

\section{Study Area}

Our study area was located in Custer and Fall River Counties in southwestern South Dakota (Fig. 1). The area $\left(1213 \mathrm{~km}^{2}\right)$ consisted of interspersed public and private land in the southern portion of the Black Hills physiographic region (Johnson et al. 1995). Elevations ranged from $930 \mathrm{~m}$ to $1627 \mathrm{~m}$ above mean sea level. The climate was continental with mean annual precipitation of $44 \mathrm{~cm}$ and mean annual temperature of $8^{\circ} \mathrm{C}$ (National Climatic Data Center 1971-2000). The study area was mostly ponderosa pine forest (48\%) and meadows (23\%). Twenty-nine percent of the study area was burned by wildfires in 2000 and 2001. Rare $(<1 \%)$ stands of Rocky Mountain juniper (Juniperus scopulorum) and deciduous draws also occurred. Western snowberry (Symphoricarpos occidentalis) and common juniper (Juniperus communis) were common shrubs in the understory, while serviceberry (Amelanchier alnifolia), bearberry, and chokecherry (Prunus virginiana) occurred less frequently (Hoffman and Alexander 1987). Predominant native grasses included needle-and-thread (Stipa comata), western wheatgrass (Pascopyrum smithii), blue grama (Bouteloua gracilis), little bluestem (Schizachy- rium scoparium), and prairie dropseed (Sporobolus heterolepis; Larson and Johnson 1999).

\section{Methods}

Capture, Radiotelemetry, and Weather

We captured Wild Turkeys during winter (1 December-31 March 2001-2004) using cannon nets (Dill and Thornsberry 1950, Austin et al. 1972), rocket nets (Thompson and Delong 1967, Wunz 1984), and drop nets (Glazener et al. 1964). Following capture, we aged female Wild Turkeys as adult ( $>1$ year old) or yearling ( $<1$ year old) based on presence or absence of barring on the 9th and 10th primary feathers (Williams 1961). We fitted Wild Turkeys with 98-g backpack-mounted radio-transmitters equipped with activity signals and a mercury switch mortality sensor set to activate after 8 hours of inactivity; model R2000 receivers were used to locate radio-marked Wild Turkeys (Advanced Telemetry Systems, Isanti, MN).

We located Wild Turkeys by direct observation with handheld Yagi antennae 5-6 days each week. To avoid temporal bias, we located Wild Turkeys during different time periods (morning: sunrise to 1000 hours; midday: 1001 hours to 1400 hours; afternoon: 1401 hours to sunset). We located all radio-marked Wild Turkeys systematically during each of these time periods during winter, and locations for 
TABLE 1. Selection of vegetation structural stages (macrohabitats) for foraging by radio-marked female Merriam's turkeys during winter (1 December-31 March) in the southern Black Hills, South Dakota, 2001-2004.

\begin{tabular}{|c|c|c|c|c|c|c|}
\hline \multicolumn{3}{|c|}{ Vegetation structural-stage categories ${ }^{a}$} & \multirow[b]{2}{*}{$\begin{array}{c}\text { Available } \\
\text { proportion }^{b}\end{array}$} & \multirow[b]{2}{*}{$\begin{array}{l}\text { Use } \\
\text { counts }\end{array}$} & \multirow[b]{2}{*}{$\begin{array}{c}\text { Selection } \\
\text { ratio (C.I.) }\end{array}$} & \multirow[b]{2}{*}{ Utilization $^{\mathrm{c}}$} \\
\hline Macrohabitat class & $\begin{array}{l}\mathrm{DBH} \\
\text { class }\end{array}$ & $\begin{array}{c}\text { Overstory } \\
\text { canopy }\end{array}$ & & & & \\
\hline Farmstead $^{\mathrm{d}}$ & - & - & $<0.01$ & 107 & - & + \\
\hline Meadow & - & - & 0.23 & 42 & $0.86(0.50-23)$ & 0 \\
\hline Ponderosa pine & Shrub/sapling & & 0.01 & 4 & $1.35(-27-98)$ & 0 \\
\hline Ponderosa pine & $2.54-22.9 \mathrm{~cm}$ & $0-40$ & 0.06 & 10 & $0.79(0.00-59)$ & 0 \\
\hline Ponderosa pine & $2.54-22.9 \mathrm{~cm}$ & $41-70$ & 0.08 & 10 & $0.63(0.20-06)$ & 0 \\
\hline Ponderosa pine & $2.54-22.9 \mathrm{~cm}$ & $71-100$ & 0.04 & 8 & $1.08(0.21-96)$ & 0 \\
\hline Ponderosa pine & $>22.9 \mathrm{~cm}$ & $0-40$ & 0.14 & 69 & $2.39(1.68-10)$ & + \\
\hline Ponderosa pine & $>22.9 \mathrm{~cm}$ & $41-70$ & 0.12 & 57 & $2.20(1.32-07)$ & + \\
\hline Ponderosa pine & $>22.9 \mathrm{~cm}$ & $71-100$ & 0.03 & 9 & $1.64(-14-42)$ & 0 \\
\hline Wildfire-burned & - & - & 0.29 & 2 & $0.03(-03-09)$ & - \\
\hline Rare & - & - & $<0.01$ & 0 & $0.00(0.00-0.00)$ & 0 \\
\hline 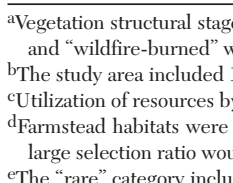 & $\begin{array}{l}\text { vere described based } \\
\text { added as macrohabi } \\
274.4 \text { ha, and the apr } \\
\text { ild Turkeys was categ } \\
\text { ized more than avail } \\
\text { affect other coefficien }\end{array}$ & $\begin{array}{l}\text { vegetation type, } \\
\text { imate area for ea } \\
\text { zed as follows: ut } \\
\text { but were not in }\end{array}$ & $\begin{array}{l}\text {, and overstory c } \\
\text { tegory can be ca } \\
\text { l more than avail } \\
\text { ed in chi-square }\end{array}$ & $\begin{array}{l}\text { cover (Butt } \\
\text { using the } \\
\text { ), equal ut } \\
\text { s because }\end{array}$ & $\begin{array}{l}\text { d Gillam 1983). The ca } \\
\text { ble proportions. } \\
\text { i (0), and utilized less } \\
\text { pected values were < }\end{array}$ & $\begin{array}{l}\text { ories "farmsteads" } \\
\text { available (-). } \\
\text { d because such a }\end{array}$ \\
\hline
\end{tabular}

individuals were evenly distributed across the sampling period. We obtained visual observations by carefully approaching Wild Turkeys so as to not disturb their foraging. Foraging behavior was determined by visually observing radio-marked Wild Turkeys scratching and consuming natural food items or cereal grains. After turkeys left the area, investigators immediately obtained exact coordinates of the foraging locations with a geographic positioning system (GPS). Only observations of foraging female Wild Turkeys that were not disturbed and whose behavior appeared natural were used in analyses. Most observations of Wild Turkeys included only 1 radio-marked individual in a flock. However, during winter, flocking behavior resulted in occasions when spatial independence among radio-marked individuals did not occur. On these occasions, we used the flock as the experimental unit for that observation.

Temperature $\left({ }^{\circ} \mathrm{C}\right)$ and snow depth $(\mathrm{cm})$ were recorded daily close to the center of the study area, which was near Pringle, South Dakota. Snow depth was measured from 3 randomly selected sites in both meadow and ponderosa pine habitats. The proportion of days that snow covered the ground during the winter period was also recorded as a discrete variable (i.e., bare ground [0] or snow-covered ground [1]) at the field station.

\section{Habitat Descriptions}

Macrohabitat.-We determined habitat availability at the 3rd-order (macrohabitat) scale of resolution (Johnson 1980) by constructing a $100 \%$ minimum convex polygon of all female Wild Turkey locations using the Home Range Extension (HRE; Rodgers and Carr 1998) within ArcView 3.3 (ESRI 1996). We intersected this area using a geographic information system (GIS) with the Black Hills National Forest Service Resource Information System (RIS) GIS coverage (Black Hills National Forest Vegetation Database, USDA Supervisors Office, Custer, SD, 2000). Vegetation descriptions of these macrohabitat polygons by the Black Hills National Forest were based on 5 sample plots systematically located in each polygon as part of the established RIS inventory protocol. Vegetation polygons in the RIS coverage were described using a hierarchical classification based on vegetation types and structural stages (Buttery and Gillam 1983). We delineated polygons of vegetation on private land within the area and assigned vegetation type and structural stages by comparing these polygons with classified polygons from adjacent Forest Service land using 1:24,000 aerial photographs and digital orthophotographs to aid our interpretation. Vegetation structural stages of macrohabitats included grass/forb (meadow), shrub/ sapling, pole stands $(2.54-22.9 \mathrm{~cm} \mathrm{DBH})$, and 
mature/saw timber stands $(>22.9 \mathrm{~cm} \mathrm{DBH})$ with overstory canopy cover categories in pole and mature/saw timber forest of $0 \%-40 \%, 41 \%-$ $70 \%$, and $>70 \%$. Rare habitats that comprised $<1 \%$ of the area included deciduous draws and shrubs. Additionally, we added the categories of "farmsteads" and "wildfire burned." The farmstead category represented areas within pastures or corral systems where livestock were being fed grain and where Wild Turkeys could forage on oat bales, spillage, or undigested grain within livestock fecal material. The wildfireburned category included areas from the Jasper Fire (summer 2000) and the Rogers Shack Fire (summer 2001). This classification scheme resulted in 11 vegetation structural-stage categories (Table 1).

MicrohabiTat.-To estimate microhabitats selected by female Wild Turkeys relative to available microhabitat, we used stratified random sampling (Cochran 1977) within our study area. Strata for the random sampling were the vegetation structural stages of non-farmstead and unburned macrohabitats described above. Using GIS, we randomly selected all polygons of the same vegetation structural stage, and from these we randomly selected 15 polygons without replacement. Within each of these polygons we selected 1 random point from a 30-m grid. We measured the vegetation at these random points and at the locations where we observed Wild Turkeys foraging. Sites where Wild Turkeys were observed were measured 1-2 days after the locations were collected. Vegetation characteristics were quantified along a 60-m transect centered where Wild Turkeys were observed, or over the random point. Data collected along transects were averaged for each site. Overstory canopy cover (OCC) was estimated with 50 point measurements at $1-\mathrm{m}$ intervals along the transect using a GRS densitometer (Stumpf 1993). Understory visual obstruction (VOR) was measured at 5-m intervals $(n=12)$ along the transect using a modified Robel pole (Robel et al. 1970) marked with alternating colors at 2.54-cm increments (Benkobi et al. 2000). The pole was placed $4 \mathrm{~m}$ from the investigators, and investigators kneeled to a height of $1 \mathrm{~m}$ while collecting VOR readings (Robel et al. 1970). At the same time, observers also measured, with a ruler, heights of grasses, forbs, and shrubs from each of the cardinal directions. A $20 \times 50$-cm quadrat was used to estimate percent understory canopy cover (Daubenmire 1959) of total cover, grass, forbs, shrubs, and dominant plant species at $2-\mathrm{m}$ intervals $(n=30)$ along transects. Tree characteristics were measured in 3 plots with 1 at the midpoint of the transect and 1 at each end of the transect ( $30 \mathrm{~m}$ away). We recorded all trees $\geq 15.24 \mathrm{~cm} \mathrm{DBH}$ in a variable-radius plot using a 10-factor prism (Sharpe et al. 1976). We recorded data for trees $<15.24 \mathrm{~cm} \mathrm{DBH}$ in a 5.03-m fixed-radius plot. We used a compass to measure aspect, defined as the prevailing downhill direction on a hillside; we used a clinometer to estimate percent slope along this same gradient. Downed woody debris (mtons • $\mathrm{ha}^{-1}$ ) was interpolated using a pictorial guide (Simmons 1982). Distance (m) to the nearest edge, such as a meadow-ponderosa pine forest interface, was paced and these measurements were truncated at $100 \mathrm{~m}$.

Pine seed abundance and use was measured from 1 November through 31 March 2001-2003. Most ponderosa pine seeds are deposited onto the ground from pinecones by 1 November (Krugman and Jenkinson 1974, Oliver and Ryker 1990). We used a proportional sample random design (Cochran 1977) to estimate pine seeds from 291 random sites within the study area. Along a 60-m transect, 12 pine seed samples were collected at 5-m intervals using a sieve. We collected $2.54 \mathrm{~cm}$ of debris from the surface of a $20 \times 50-\mathrm{cm}$ quadrat and placed it in a sieve where pine seeds were separated and counted. We quantified forest characteristics at these sites using the same procedures described in the previous paragraph.

\section{Analyses}

Macrohabitat.-For statistical analyses, on most occasions radio-marked female Wild Turkeys were the experimental unit, and in rare instances, flocks were the experimental unit. We used the Design II analysis (Manly et al. 1993) to estimate selection of macrohabitat categories by female Merriam's turkeys during winter. Chi-square analysis was used to compare observed use points with expected use, which was estimated from available habitats within the study area. We pooled rare habitats that comprised $<1 \%$ of the area for these analyses. Significance was determined at $\alpha=$ 0.10 , and $P$-values for selection of macrohabitats were adjusted using the Bonferroni inequality (Miller 1981) to maintain experimentwise error rates at the predetermined $\alpha$. The 
Bonferroni adjustment included $k=10$ habitat categories.

Microhabitat.-We summarized microhabitat characteristics for random sites and sites where Wild Turkeys were observed foraging during winter. For analyses of resource selection by female Wild Turkeys during winter, we included a weight factor to accommodate deviations from proportional sampling among random strata (Cochran 1977). Each random site was assigned a weight equaling $\mathrm{P}_{i} \cdot \mathrm{N}_{t} / \mathrm{N}_{i}$, where $\mathrm{P}_{i}$ was the proportion of the entire study area that was composed of a particular stratum $i$ (vegetation structural stage), $\mathrm{N}_{t}$ was the total number of random samples, and $\mathrm{N}_{i}$ was the number of random samples in a particular stratum $i$. Sites where we observed Merriam's turkeys received a weight of 1.0. We then conducted a Kolmogorov-Smirnov (K-S) 2-sample distribution test (SAS Institute 2000) to assess differences in distributions of characteristics at random sites and at Wild Turkey foraging sites.

We used the multiple-response permutation procedure (MRPP, Mielke and Berry 2001) to test the hypothesis that pine seed foraging behavior does not occur randomly across the landscape (i.e., female Wild Turkeys would select for sites with more ponderosa pine seeds than random sites) for the winters of 20012002 and 2002-2003. MRPP is a distribution test, based on Euclidean distance, of the hypothesis that the data sets are from the same population. MRPP tests relax the parametric structure requirement of a test statistic and are less affected by an extreme measurement of a single object. Analysis of Variance (ANOVA) and chi-square statistics were used to compare snow depth among years (SAS Institute 2000).

To estimate selection of resources from available habitat, we used the information-theoretic approach (Burnham and Anderson 1998, 2002) of plausible models (Guthery et al. 2005) after initial screening of variables from the K-S tests and collinearity evaluation. Collinearity was assessed using principal components analysis followed by a Varimax factor rotation using PROC FACTOR in SAS (Kaiser 1958, SAS Institute 2000). We developed 2 sets of logistic models for use of resources. Logistic regression functions more like a logistic discriminant model when the availability function is not clearly defined relative to unused habitats (Keating and Cherry 2004). The 1st set of mod- els estimated factors associated with selection by female Merriam's turkeys of farmsteads versus forests for foraging ( $n=10$ models evaluated). The dependent variable was categorical: (0) Wild Turkey did not visit farmstead or (1) Wild Turkey did visit farmstead. Variables used to estimate whether Wild Turkeys selected farmsteads or forests as forage areas included snow depth (Porter et al. 1980, Lehman 1998), average daily temperature (Haroldson et al. 2001), pine seed abundance (Rumble and Anderson 1996a, 1996b), and interactions of those variables. We hypothesized that foraging sites of Merriam's turkeys would depend on conditions affecting availability of an important food, namely, ponderosa pine seeds (e.g., Rumble and Anderson 1996a).

The 2nd set of models estimated selection of forest characteristics associated with Wild Turkey foraging sites $(n=26$ models evaluated). The dependent variable was categorical: (0) available forest site within the study area or (1) forest use site by Wild Turkey. Variables used in plausible models were based on a priori information (e.g., Wakeling and Rogers 1995, Rumble and Anderson 1996a, 1996b, Wakeling and Rogers 1996). Variables considered in model development included large-tree density (trees $\geq 15.24 \mathrm{~cm}$ DBH per ha), large-tree DBH $(\mathrm{cm})$, understory shrub cover $(\%)$, total herbaceous understory cover $(\%)$, woody debris (mtons $\left.\cdot \mathrm{ha}^{-1}\right)$, VOR $(\mathrm{cm})$, small-tree density (number of trees $<15.24 \mathrm{~cm}$ DBH per ha), small-tree DBH $(\mathrm{cm})$, slope $(\%)$, and distance to edge (m). Wild Turkeys may utilize understory shrubs and particular shrub species during winter (Rumble and Anderson 1996a), and understory vegetation influenced the selection of foraging sites by Merriam's turkeys in Arizona and the central Black Hills (Wakeling and Rogers 1995, Rumble and Anderson 1996b). We hypothesized that Wild Turkeys would select foraging sites with less VOR and understory vegetation cover.

Logistic models were compared using Akaike's information criterion $\left(\mathrm{QAIC}_{c}\right.$; Burnham and Anderson 2002). QAIC ${ }_{c}$ was computed using the log likelihood, number of parameters $(\mathrm{K})$, and modified for overdispersed count data with a variance inflation factor $(\hat{c})$. Rank importance of variables was estimated using the summation of Akaike weights $\left(\mathrm{w}_{i} \mathrm{~s}\right.$; Burnham and Anderson 2002). Additionally, we calculated unit odds ratios and 95\% confidence 
intervals to further evaluate importance of variables (Hosmer and Lemeshow 2000). We used receiver operating characteristic (ROC) curves (SAS Institute 2000) to evaluate the predictive capabilities of logistic models (Hosmer and Lemeshow 2000).

To further examine the scale at which habitats were selected during winter, we compared microhabitat characteristics of random sites and foraging sites of turkeys within vegetation structural stages or macrohabitats. For continuous variables, we used MRPP (Mielke and Berry 2001) and chi-square contingency tables to compare the categorical variable aspect within vegetation structural stages (SAS Institute 2000). We hypothesized that Wild Turkeys would not show selection of forest characteristics that differed from those describing the vegetation structural stage. Significance for these tests was determined at $\alpha=0.10$. Our research was conducted in an effort to provide forest managers with information on how forest management might affect Wild Turkeys. Because forest management such as logging effects longterm changes to forest vegetation, committing a type II error would be equivalent to incorrectly suggesting Wild Turkeys use habitats randomly. Consequently, we selected a more liberal $\alpha$-level so as not to preclude management that is beneficial to Merriam's turkeys in forest ecosystems.

\section{RESUlts}

\section{Habitat Selection}

Macrohabitat Resource Selection.The study area included 9159 habitat units accounting for 121,274 ha. Over the 4-year study period, 86 female Wild Turkeys $(n=70$ adults, $n=16$ yearlings) were included in our analyses, resulting in 318 foraging sites. Because some Merriam's turkeys were never located away from farmstead areas during winter and some were always with other radio-marked individuals, the test of habitat use among individuals was conducted using 50 individuals. There were no differences $\left(c^{2}\right.$ $=300.22 \mathrm{df}=441, P=1.00)$ in use of habitats among individual turkeys that were in the forest. However, resource use was not proportional to resource availability $\left(c^{2}=182.26\right.$, $\mathrm{df}=9, P<0.001)$ at the macrohabitat level. Farmsteads were utilized by Wild Turkeys more than expected (Table 1). Farmstead habitats
TABLE 2. Pine seed abundance per $\mathrm{m}^{2}$ beneath random ponderosa pine stands and beneath pine stands at Wild Turkey foraging sites in the southern Black Hills, South Dakota, 2001-2003.

\begin{tabular}{|c|c|c|c|c|}
\hline & \multicolumn{2}{|c|}{ 2001-2002 } & \multicolumn{2}{|c|}{$2002-2003$} \\
\hline & Mean & $s_{\bar{x}}$ & Mean & $s_{\bar{x}}$ \\
\hline Random pine stands & 27.20 & 4.87 & 5.96 & 1.15 \\
\hline \multicolumn{5}{|l|}{ Pine stands at Wild } \\
\hline Turkey foraging sites & 152.00 & 11.05 & 11.80 & 4.71 \\
\hline $\begin{array}{l}\text { MRPP statistic for } \\
\text { years comparison } \\
(P \text {-values })^{\mathrm{a}}\end{array}$ & $-30.38(P$ & $0.01)$ & $-1.12(P$ & $=0.12)$ \\
\hline
\end{tabular}

$\overline{\text { aRandom sites and foraging sites were compared using a multiple-response }}$ permutation procedure (MRPP) at a significance level of $\alpha=0.10$.

were not included in chi-square analysis because of low availability ( $<1 \%$ of samples), large sample size of use sites, and sensitivity of the analysis to such extreme sample sizes. Resource analysis indicated that pine categories $>22.9 \mathrm{~cm}$ DBH with $0 \%-40 \%$ canopy cover and $41 \%-70 \%$ canopy cover were utilized more than expected based on availability (Table 1). Wildfire-burned habitat was utilized proportionally less than its availability, and equal utilization occurred for the remaining categories. Rare habitats, or deciduous draw and shrub communities, were not used or their use was not detected $(n=0)$; however, little land area of this category $(<1 \%)$ was available to Wild Turkeys (Table 1).

Weather, Pine Seed Abundance, and Farmstead Resource Selection.-Mean ambient temperatures by month were similar for 2001 and 2003, somewhat warmer in 2004, and colder for January and March in 2002. Snow depth differed among years both in meadows $\left(F_{3,380}=10.78, P<0.0001\right)$ and in pine habitats $\left(F_{3,380}=8.81, P<0.0001\right)$, with greatest snow depth occurring in 2001. However, number of days that snow covered the ground did not differ among years $\left(\chi^{2}=4.04\right.$, $\mathrm{df}=3, P=0.13)$. Pine seed abundance varied by years and by habitats as maximum pine seed production occurred in ponderosa pine stands with trees of 30-35 cm DBH and averaging 22-28 $\mathrm{m}^{2} \cdot \mathrm{ha}^{-1}$ basal area. During winter 2001-2002, turkey foraging sites $(n=43$, $\left.\bar{x}=152.00, s_{\bar{x}}=11.05\right)$ had 5 times more $(P<0.001)$ pine seeds than random pine sites $\left(n=96, \bar{x}=27.20, s_{\bar{x}}=4.87\right.$; Table 2). Although seed production at Wild Turkey foraging sites was twice as high as at random 
TABLE 3. Best set of candidate logistic models predicting use of farmstead sites during winter (1 December-31 March) by female Merriam’s turkeys in the southern Black Hills, South Dakota, 2001-2004

\begin{tabular}{|c|c|c|c|c|c|c|}
\hline Candidate models & $\mathrm{K}$ & $\log (L(\theta))^{\mathrm{a}}$ & $\mathrm{QAIC}_{c}^{\mathrm{b}}$ & $\Delta \mathrm{QAIC}_{c}{ }^{\mathrm{c}}$ & $\mathrm{w}_{i}{ }^{\mathrm{d}}$ & ERe \\
\hline \multicolumn{7}{|l|}{$u=-0.97-0.02($ temperature $)$} \\
\hline$-0.07($ pine seed) & 3 & 1474.28 & 767.56 & 0.00 & 0.48 & 1.00 \\
\hline$u=-0.91-0.07$ (pine seed) & 2 & 1479.10 & 768.05 & 0.48 & 0.38 & 1.27 \\
\hline$u=-0.90-0.07$ (pine seed) & & & & & & \\
\hline-0.01 (snow depth) & 3 & 1478.80 & 769.90 & 2.33 & 0.15 & 3.21 \\
\hline $\begin{array}{c}u=-1.46+0.003(\text { pine seed } * \\
\text { temperature } * \text { snow depth) }\end{array}$ & 4 & 1497.40 & 781.52 & 13.95 & 0.00 & 1071.1 \\
\hline
\end{tabular}

aFisher's maximum likelihood estimates $(-2 \cdot \operatorname{loglikelihood})$.

bAkaike's information criterion (AIC) modified for a variance inflation factor $\left(\hat{\mathrm{c}}=1.94\right.$ ) when count data is over-dispersed $\left(\mathrm{QAIC}_{C}\right)$.

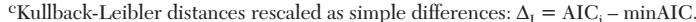

${ }^{\mathrm{d}}$ Strength of evidence for models or model weights $\left(\mathrm{w}_{i}\right)$ computed as a ratio: $\exp \left(-\Delta_{\mathrm{I}} / 2\right) / \sum \exp \left(-\Delta_{\mathrm{I}} / 2\right)$.

eEvidence ratios (best model $w_{\mathrm{i}} / w_{\mathrm{j}}$ competing models) used to compare models.

TABLE 4. Relative variable importance (RVI) and odds ratios (95\% confidence intervals) of variables predicting use of farmstead and forest foraging sites by Merriam's turkeys in the southern Black Hills, South Dakota, 2001-2004. Odds ratios were calculated for only those variables in models with evidence ratios $\leq 4$.

\begin{tabular}{|c|c|c|c|}
\hline \multirow[b]{2}{*}{ Variable } & \multicolumn{3}{|c|}{ Farmstead resource selection diagnostics } \\
\hline & $\mathrm{RVI}^{\mathrm{a}}$ & Odds ratio $^{b}$ & Confidence interval \\
\hline Pine seeds $\left(\mathrm{m}^{2}\right)$ & 1.00 & $0.93^{\mathrm{c}}$ & $0.92-0.95^{\mathrm{c}}$ \\
\hline Temperature $\left({ }^{\circ} \mathrm{C}\right)$ & 0.48 & $0.98^{\mathrm{c}}$ & $0.96-1.00^{\mathrm{c}}$ \\
\hline \multirow[t]{2}{*}{ Snow depth $(\mathrm{cm})$} & 0.15 & $0.99^{\mathrm{d}}$ & $0.94-1.03^{\mathrm{d}}$ \\
\hline & \multicolumn{3}{|c|}{ Forest resource selection diagnostics } \\
\hline Variable & RVIa & Odds ratio $^{\mathrm{b}}$ & Confidence interval \\
\hline Total herbaceous understory cover (\%) & 1.00 & $0.94^{\mathrm{e}}$ & $0.91-0.96 \mathrm{e}^{\mathrm{e}}$ \\
\hline Visual obstruction $(\mathrm{cm})$ & 0.98 & $0.80^{\mathrm{e}}$ & $0.66-0.93^{\mathrm{e}}$ \\
\hline Large-tree diameter at breast height $(\mathrm{cm})$ & 0.96 & $1.11^{\mathrm{e}}$ & $1.03-1.21^{\mathrm{e}}$ \\
\hline Large-tree density (ha) & 0.69 & $0.99 \mathrm{e}$ & $0.99-1.00 \mathrm{e}$ \\
\hline
\end{tabular}

aRelative variable importance (RVI) was calculated by adding Akaike weights for all models in the model set in which the variable was present.

bUnit odds ratios $>1$ indicate a positive relationship and $<1$ indicate a negative relationship with the response variable.

codds ratios (95\% confidence intervals) taken from top farmstead use prediction model (pine seed, temperature) from Table 4.

dOdds ratio (95\% confidence interval) taken from 3rd-best farmstead use prediction model (pine seed, snow depth) from Table 4 .

e Odds ratios (95\% confidence interval) taken from top forest-use prediction model (total understory cover, visual obstruction, large-tree diameter at breast height, and large-tree density) from Table 6.

sites in 2002-2003, the difference was not statistically significant (Table 2 ).

The best model for predicting selection of farmstead resources included 2 variables: pine seed abundance and temperature. The top 3 plausible models all included pine seed abundance, and all of these models had similar capability for predicting farmstead resource selection $\left(\triangle \mathrm{QAIC}_{c}\right.$ range $0.00-2.33$; Table 3$)$. The remaining models were less effective in predicting farmstead resource selection $(\Delta$ $\mathrm{QAIC}_{c} \geq 13.95$; Table 3). Predictive capability for the best model was marginally adequate because the ROC $=0.66$. Pine seed abundance $\left(\mathrm{w}_{i} \mathrm{~s}=1.00\right)$ had the highest association with whether Wild Turkeys foraged in farmsteads or in forests. Pine seed abundance was followed by temperature $\left(\mathrm{w}_{i} \mathrm{~s}=0.48\right)$ and snow depth $\left(\mathrm{w}_{i} \mathrm{~s}=0.15\right)$ in variable importance (Table 4). Odds ratios indicated that pine seed abundance was negatively associated with farmstead use and that Merriam's turkeys were more likely to forage in farmstead habitats during years when ponderosa pine seeds were lower in abundance (Table 4).

Microhabitat Resource Selection.Within the forested landscape, 63 foraging sites and 170 stratified random sites were characterized (Table 5). Qualitative analysis of the explanatory variables revealed collinearity among large-tree density, basal area, and canopy cover. Only large-tree density was used in model development. Additionally, vegetation height, total herbaceous understory cover, grass 
Table 5. Explanatory habitat variables for analyzing winter habitat selection in the southern Black Hills, South Dakota, 2001-2004. This table includes means, standard errors $\left(s_{\bar{x}}\right)$, and $P$-values associated with comparisons between foraging sites and random sites across the study area.

\begin{tabular}{|c|c|c|c|c|c|}
\hline Variable & Foraging sites & $s_{\bar{x}}$ & Random sites & $s_{\bar{x}}$ & $P$-value ${ }^{a}$ \\
\hline Overstory canopy cover (\%) & 48.4 & 2.7 & 27.7 & 1.8 & $<0.01$ \\
\hline Slope $(\%)$ & 10.4 & 0.9 & 9.2 & 0.5 & 0.17 \\
\hline Aspectb & \multicolumn{4}{|c|}{ Overall aspect chi-square test: } & $<0.01$ \\
\hline North & 4 & - & 36 & - & - \\
\hline East & 13 & - & 38 & - & - \\
\hline South & 30 & - & 48 & - & - \\
\hline West & 7 & - & 48 & - & - \\
\hline Woody debris (mtons $\left.\cdot \mathrm{ha}^{-1}\right)$ & 6.9 & 0.64 & 7.8 & 0.51 & 0.52 \\
\hline Distance to edge $(\mathrm{m})$ & 54.0 & 4.95 & 60.3 & 2.87 & 0.75 \\
\hline Basal area $\left(\mathrm{m}^{2} \cdot \mathrm{ha}^{-1}\right)^{\mathrm{c}}$ & 16.0 & 1.02 & 12.6 & 0.83 & $<0.01$ \\
\hline Large-tree density (ha) c & 252.7 & 18.21 & 257.7 & 19.00 & $<0.01$ \\
\hline Large-tree diameter at breast height $(\mathrm{cm})$ & 28.5 & 0.68 & 24.1 & 0.82 & $<0.01$ \\
\hline Visual obstruction $(\mathrm{cm})$ & 2.9 & 0.34 & 5.9 & 0.36 & $<0.01$ \\
\hline Vegetation height $(\mathrm{cm})$ & 2.8 & 0.42 & 17.4 & 1.02 & $<0.01$ \\
\hline Small-tree density (ha) d & 372.7 & 78.35 & 395.4 & 72.79 & 0.17 \\
\hline Small-tree diameter at breast height $(\mathrm{cm})$ & 6.8 & 0.49 & 6.0 & 0.33 & 0.11 \\
\hline Total herbaceous understory cover $(\%)$ & 16.4 & 2.54 & 50.1 & 2.48 & $<0.01$ \\
\hline Grass cover $(\%)$ & 14.4 & 2.35 & 40.0 & 2.69 & $<0.01$ \\
\hline Forb cover $(\%)$ & 0.3 & 0.11 & 10.4 & 1.28 & $<0.01$ \\
\hline Shrub cover $(\%)$ & 1.6 & 0.44 & 8.8 & 0.98 & $<0.01$ \\
\hline Prunus virginiana $(\%)$ & 0.2 & 0.10 & 0.0 & 0.00 & 0.56 \\
\hline Schizachyrium scoparium (\%) & 2.5 & 0.51 & 0.0 & 0.00 & $<0.01$ \\
\hline Symphoricarpos occidentalis (\%) & 0.5 & 0.37 & 3.1 & 0.53 & $<0.01$ \\
\hline Bouteloua curtipendula $(\%)$ & 2.0 & 0.54 & 1.1 & 0.28 & $<0.01$ \\
\hline Poa pratensis $(\%)$ & 5.2 & 1.60 & 17.5 & 2.21 & 0.01 \\
\hline Stipa virudula $(\%)$ & 0.8 & 0.26 & 1.5 & 0.29 & 0.39 \\
\hline Elytrigia intermedia (\%) & 0.1 & 0.07 & 1.5 & 0.43 & 0.01 \\
\hline Carex richardsonii $(\%)$ & 0.1 & 0.03 & 1.9 & 0.45 & $<0.01$ \\
\hline Achillea millefolium (\%) & 0.0 & 0.00 & 1.3 & 0.29 & $<0.01$ \\
\hline Bromus inermis (\%) & 0.0 & 0.00 & 4.3 & 1.06 & 0.03 \\
\hline Stipa comata $(\%)$ & 0.0 & 0.00 & 1.0 & 0.35 & 0.02 \\
\hline Arctostaphylos uva-ursi (\%) & 0.0 & 0.00 & 1.4 & 0.42 & 0.33 \\
\hline
\end{tabular}

aSites compared with either a chi-square test or a Kolmogorov-Smirnov test.

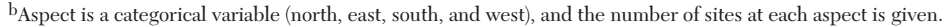

cBasal area and density of trees $\geq 15.24 \mathrm{~cm}$ diameter at breast height were estimated in a variable-radius plot using a 10-factor prism (Sharpe et al. 1976).

dDensity of small trees ( $<15.24 \mathrm{~cm}$ diameter at breast height) was estimated in a fixed plot having a 5.03-m radius.

cover, and Kentucky bluegrass (Poa pratensis) were also correlated, but only total ground cover was included for model development. Several variables differed between random and foraging sites (Table 5), suggesting some resource selection; therefore, several of these variables were used in resource selection models. Foraging sites within the forest were best predicted by having less total herbaceous understory vegetation, less VOR, greater DBH of trees $\geq 15.24 \mathrm{~cm}$, and lower density of trees $\geq 15.24 \mathrm{~cm} \mathrm{( \triangle} \mathrm{QAIC}_{c}$ range $0.00-1.47$; Tables $5,6)$. The remaining models were less effective in predicting foraging sites $\left(\Delta \mathrm{QAIC}_{c} \geq\right.$ 5.36; Table 6). Logistic modeling indicated that support for the best model was substantial (weight of evidence $\left[\mathrm{w}_{i}\right]=0.61$ ) and that classification accuracy of the model was excellent $(\mathrm{ROC}=0.89)$.

Total herbaceous understory cover $\left(\mathrm{w}_{i} \mathrm{~s}=\right.$ 1.00), VOR $\left(\mathrm{w}_{i} \mathrm{~s}=0.98\right)$, and large-tree DBH $\left(\mathrm{w}_{i} \mathrm{~s}=0.96\right)$ had the greatest weights among the variables within models, and large-tree density was somewhat less influential $\left(\mathrm{w}_{i} \mathrm{~s}=\right.$ 0.69; Table 4). Total herbaceous understory cover and VOR were negatively associated with forest foraging sites (odds ratios < 0.94); large-tree DBH was positively associated with foraging sites (odds ratio $=1.11$ ), and largetree density had little association with foraging sites (odds ratio $=0.99$, Table 4).

Selection Within Structural-Stage CAtEgories.-Further analysis within each major structural-stage category indicated that 
TABLE 6. Best set of candidate logistic models predicting use of foraging sites across all structural-stage categories during winter (1 December-31 March) within the forest by female Merriam’s turkeys in the southern Black Hills, South Dakota, 2001-2004.

\begin{tabular}{|c|c|c|c|c|c|c|}
\hline Candidate models & $\mathrm{K}$ & $\log (L(\theta))^{\mathrm{a}}$ & $\mathrm{QAIC}_{c}^{\mathrm{b}}$ & $\Delta \mathrm{QAIC}_{c}^{\mathrm{c}}$ & $\mathrm{w}_{i}^{\mathrm{d}}$ & $\mathrm{ERe}^{\mathrm{e}}$ \\
\hline \multicolumn{7}{|c|}{$\begin{array}{l}u=-0.07-0.003 \text { (large-tree density })+0.10 \text { (large-tree diameter at breast height })-0.22(\text { visual obstruction })- \\
0.07 \text { (total understory cover })\end{array}$} \\
\hline & 5 & 132.63 & 142.90 & 0.00 & 0.63 & 1.00 \\
\hline \multicolumn{7}{|c|}{$u=-1.72+0.14$ (large-tree diameter at breast height $)-0.26$ (visual obstruction) -0.06 (total understory cover) } \\
\hline & 4 & 136.19 & 144.37 & 1.47 & 0.30 & 2.08 \\
\hline \multicolumn{7}{|c|}{$u=2.92-0.003$ (large-tree density) -0.07 (total understory cover) -0.23 (visual obstruction) } \\
\hline & 4 & 140.08 & 148.26 & 5.36 & 0.04 & 14.6 \\
\hline
\end{tabular}

foraging sites differed $(P \leq 0.10$; Table 7$)$ from random sites in several characteristics. Overstory canopy cover (OCC) was variable within structural stages, as OCC was greater for random sites in 2 pole size $(2.54-22.9 \mathrm{~cm} \mathrm{DBH})$ categories ( $0 \%-40 \%$ and $>70 \%$ OCC). However, within the mature pine category $(>22.9$ cm DBH) with 41\%-70\% OCC, OCC was greater for Wild Turkey use sites. Merriam's turkeys utilized south-facing aspects within pole size (41\%-70\% OCC) and mature pine (0\%-40\% and $41 \%-70 \%$ OCC) categories. Woody debris (mtons $\cdot \mathrm{ha}^{-1}$ ) was greater for random sites than for Wild Turkey sites in mature pine with canopy cover $0 \%-40 \%$ and 41\%-70\%. Large-tree density was greater at random sites than at Wild Turkey use sites in 2 pole size categories $(0 \%-40 \%$ and $>70 \%$ OCC) and 1 mature pine category $(>70 \%$ OCC). Average large-tree DBH was greater for Wild Turkey sites than random sites in 2 pole size categories $(0 \%-40 \%$ and $>70 \%$ OCC). Within pole-sized $(2.54-22.9 \mathrm{~cm})$ trees that had $0 \%-40 \%$ OCC and $>70 \%$ OCC, there were fewer large trees per hectare at foraging sites, but Merriam's turkeys utilized sites with trees having larger DBH within those categories (Table 7). Small-tree density and small DBH were greater for random sites in pole stands within the $0 \%-40 \%$ OCC category. Vegetation height and VOR were greater at random sites than at foraging sites in most structural-stage categories. Total herbaceous understory vegetation was greater for random sites in several categories, and grass cover was greater at random sites in mature pine with $0 \%-40 \%$ OCC. Forb and shrub cover was greater for random sites than foraging sites in
2 mature pine categories $(0 \%-40 \%$ and $41 \%-$ $70 \%$ OCC; Table 7).

Within the macrohabitat categories that Merriam's turkeys selected (mature pine with 0\%-40\% and $41 \%-70 \%$ OCC), sites had less woody debris, less VOR, and less total herbaceous understory cover and vegetation height of herbaceous vegetation than random sites. Also within these categories, Wild Turkeys selected south-facing aspects.

\section{Discussion}

Selection of winter macrohabitat by Merriam's turkeys in the southern Black Hills included farmsteads and open- to mid-canopy $(0 \%-70 \%$ OCC), mature-structural-stage (>22.9 $\mathrm{cm} \mathrm{DBH)} \mathrm{ponderosa} \mathrm{pine} \mathrm{stands} \mathrm{for} \mathrm{foraging}$ sites. Selection of farmstead foraging areas by Merriam's turkeys occurs, particularly in areas where natural winter foods such as ponderosa pine seeds are frequently unavailable (Hengel 1990, Hoffman et al. 1996). In the southern Black Hills, most use by Wild Turkeys occurred at larger farmsteads or ranches that fed livestock (47\%), followed by smaller parcels of private land or ranchettes with less livestock (33\%), and fewer wildlife feeders in subdivisions $(20 \%)$. These areas (e.g., near buildings, feeding pastures, feed trays, and horse pens) provided high-energy foods such as corn, oats, and commercial pellets. The percentage of Wild Turkeys that wintered in association with farmsteads varied considerably among years. Ninety-one percent of Merriam's turkeys used farmsteads in winter of 2000-2001, 68\% in 2001-2002, 85\% in 2002-2003, and 50\% in 2003-2004 (Lehman 2005). We visually observed radio-marked Wild 


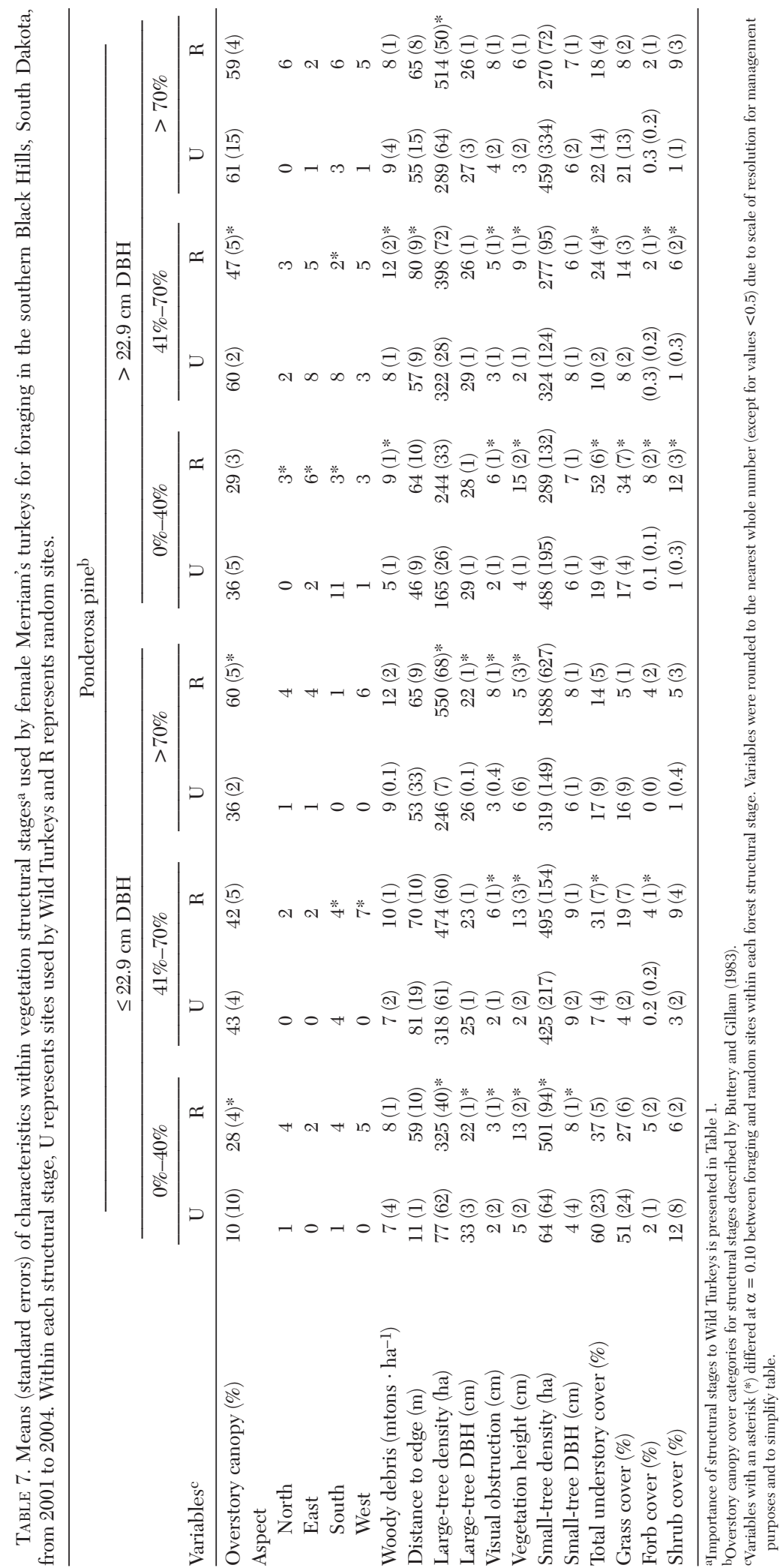


Turkeys foraging often on cereal grains obtained in farmstead areas in the early morning hours soon after leaving the roost. Later in the morning, Wild Turkeys would often move away from farmstead areas and forage on natural foods such as pine seeds, grasses, and grass seeds in the forest. In late afternoon, after sometimes moving a considerable distance throughout the day, Wild Turkeys would often return to farmstead areas to forage once again before roosting in the evening (C.P. Lehman personal observation).

These data supported our hypothesis that Merriam's turkeys in the Black Hills used cereal grains such as oats and corn more regularly during years of poor pine seed production than during years of good-to-excellent pine seed production (Rumble and Anderson 1996a, 1996b). Because habitat selection of Wild Turkeys reflects their diets (Rumble and Anderson 1996a, 1996b), Wild Turkeys should use farmsteads more when poor pine seed production occurs. Variation in use of farmsteads by birds during winter coincided with the abundance of pine seeds for the 2 years we collected seeds in the forest. Even though the model predicting use of farmsteads had less predictive capability than the model predicting use of forest resources, the relative variable importance and odds ratios for variables included in the model indicated that pine seed abundance was the most important predictor of use of farmsteads by Wild Turkeys. Goodto-excellent pine seed crops occur in 5 of 14 years, with an average frequency of 3 years in the Black Hills, and greater spring and summer precipitation can increase seed production (Boldt and Deusen 1974). During this study, precipitation from May 2002 through August $2002(28 \mathrm{~cm})$ was less than the 30 -year average $(31 \mathrm{~cm}$; National Climatic Data Center from 1971-2000), and the drier conditions may have resulted in decreased production of pine seeds, which possibly explains the increased use of farmsteads during the winter of 20022003. During drought and reduced production of pine seeds, Merriam's turkeys used other foods that had less caloric content (Rumble and Anderson 1996b). Although snow depth may influence foraging on cereal grains in some regions (Austin and DeGraff 1975, Porter et al. 1980), pine seed abundance was more important in determining selection patterns in our models.
Food resources were important in determining habitat selection by Merriam's turkeys in the southern Black Hills, and Wild Turkeys avoided wildfire-burned habitats. The severely burned habitats of the Jasper and Rogers Shack wildfires lacked live trees and ponderosa pine seed which might explain why Wild Turkeys avoided these habitats during winter. Merriam's turkeys in southeastern Montana also avoided burned areas and concentrated near ranches during winter (Thompson 1993). Female Merriam's turkeys in this study selected for a more open-canopy ponderosa pine habitat than reported for the central Black Hills (Rumble and Anderson 1993). In the central Black Hills, the greatest pine seed abundance occurred in habitats with $>70 \%$ ponderosa pine and $>28$ $\mathrm{m}^{2} \cdot \mathrm{ha}^{-1}$ basal area. In our study, the greatest pine seed abundance occurred at 22-28 $\mathrm{m}^{2}$. $\mathrm{ha}^{-1}$ basal area $\left(275-350\right.$ trees $\left.\cdot \mathrm{ha}^{-1}\right)$. Perhaps the xeric conditions of the southern Black Hills require greater spacing of trees to maximize pine seed production. In central Idaho, open ponderosa pine stands with larger average DBH produced heavier crops of larger cones than dense stands produced (Fowells 1965). Wild Turkeys also selected sites with larger trees (i.e., trees with greater DBH) in the southern Black Hills, and this was most likely related to increased pine seed production for foraging.

When Merriam's turkeys were in the forest, they also selected sites with less understory vegetation. Wild Turkeys in Arizona (Wakeling and Rogers 1996) and in the central Black Hills (Rumble and Anderson 1996b) selected winter foraging sites with less herbaceous understory vegetation. While in the forest, Wild Turkeys in the southern Black Hills foraged primarily on pine seeds directly beneath mast-producing trees with less understory vegetation cover. Presumably this allowed the Wild Turkeys to easily scratch for pine seeds within the needle litter. Our inspection of crop contents collected from unmarked female Wild Turkeys confirmed that ponderosa pine seeds were the most common food item of Wild Turkeys foraging in the forest (Lehman 2005). Ponderosa pine seeds were selected over other winter foods in the central Black Hills (Rumble and Anderson 1996a). Less visual obstruction was also an important characteristic of foraging sites. An open understory would allow foraging Wild Turkeys greater visibility of approaching predators. 
Merriam's turkeys in our study selected resources below the macrohabitat level and this was evident in selection within the major forest structural stages. Within pole-size structuralstage categories, Wild Turkeys selected sites with trees having relatively large average $\mathrm{DBH}$, further suggesting the importance of seed availability to selection patterns of Merriam's turkeys. Wild Turkeys in the southern Black Hills also selected foraging sites on southfacing aspects with a more open canopy. Wild Turkeys were observed foraging on south-facing aspects in the central Black Hills (Rumble and Anderson 1996b). South-facing aspects allow sunlight to melt snow more rapidly than on adjacent aspects and are the 1st areas to have bare ground, which facilitates scratching for pine seeds following snowfall events. Also, solar radiation at sunlit sites could reduce the metabolic cost of thermoregulation on colder days (Carrascal et al. 2001). Additionally, the drier climate of the southern Black Hills reduces the density and growth of grasses, forbs, and shrubs on the open, south-facing slopes.

Merriam's turkeys that wintered in the forest foraged primarily on ponderosa pine seeds during years of high seed abundance, but they also used more open forest and meadow habitats, and foraged primarily on grass stems when pine seeds were less abundant (Lehman 2005). Rumble and Anderson (1996b) also observed a shift in foraging to more open habitats during years of low pine seed production. However, unlike Wild Turkeys in the southern Black Hills, Wild Turkeys in the central Black Hills used bearberry fruits during years of low pine seed production. Bearberry was not abundant in the southern Black Hills and was not an important winter food for Wild Turkeys in that area.

\section{MANAGEMENT IMPLICATIONS}

In the southern Black Hills, management for open- to mid-canopy, mature-structuralstage pine stands on south-facing slopes could be beneficial for Merriam's turkeys. Stands managed for winter foraging by Wild Turkeys should have a basal area of $22-28 \mathrm{~m}^{2} \cdot \mathrm{ha}^{-1}$, or a density of $275-350$ trees $\cdot \mathrm{ha}^{-1}$, with source trees $>30 \mathrm{~cm}$ DBH. This corresponds with timber management of basal area $>23 \mathrm{~m}^{2}$. $\mathrm{ha}^{-1}$ recommended by Hoffman et al. (1993). The lack of protective cover and live trees for pine seed production made stand-replacing fire in ponderosa pine unsuitable for winter Wild Turkey habitat. High-intensity prescribed fire, or fires that damage the canopy of mature trees, will remove this habitat and should be avoided. Farmstead habitats were particularly important to Merriam's turkeys in the southern Black Hills in years of lower pine seed production. Farmsteads could be important in sustaining population levels during years of severe winter weather.

\section{ACKNOWLEDGMENTS}

We thank M. Rohfling, C. Sexton, D. Thompson, L. Flack, and C. Kassube for field support, and T. Wittig, R. King, and P. Evenson for statistical assistance. We thank cooperating landowners N. Westphal, R. (Gene) Miller, and D. Brown for providing access to lands. We appreciate the USDA Forest Service, Rocky Mountain Research Station, for providing field assistance and technical support. Funding for this research project was from the South Dakota Department of Game, Fish and Parks, Federal Aid to Wildlife Restoration Fund (Project W-75-R-132, No. 7599), National Wild Turkey Federation (National Super Fund), and the South Dakota State Chapter of the National Wild Turkey Federation (State Super Fund). Analysis and writing of this manuscript were completed while C.P. Lehman was Regional Wildlife Biologist with the National Wild Turkey Federation. Additional support was provided by South Dakota State University and McIntire-Stennis funding through the South Dakota Agricultural Experiment Station.

\section{Literature Cited}

Austin, D.H., And L.W. DeGrafF. 1975. Winter survival of Wild Turkeys in the southern Adirondacks. Proceedings of the National Wild Turkey Symposium 3:55-60.

Austin, D.H., T.E. Peoples, And L.E. Williams, Jr. 1972. Procedures for capturing and handling live Wild Turkeys. Proceedings of the Annual Conference of the Southeastern Association of Game and Fish Commission 25:222-235.

Benkobi, L., D.W. Uresk, G. Schenbeck, and R.M. King. 2000. Protocol for monitoring standing crop in grasslands using visual obstruction. Journal of Range Management 53:627-633.

Bolt, C.E., AND J.L. Deusen. 1974. Silviculture of ponderosa pine in the Black Hills: the status of our knowledge. USDA Forest Service, Research Paper RM-124, Rocky Mountain Forest and Range Experiment Station, U.S. Department of Agriculture, Fort Collins, CO. 
Burnham, K.P., And D.R. Anderson. 1998. Model selection and inference: a practical information-theoretic approach. Springer-Verlag, New York. 353 pp.

2002. Model selection and multimodel inference: a practical information-theoretic approach. 2nd edition. Springer-Verlag, New York. 488 pp.

ButTery, R.F., AND B.C. GILLAM. 1983. Forest ecosystems. Pages 34-71 in R.L. Hoover and D.L. Wills, editors, Managing forested lands for wildlife. Colorado Division of Wildlife in cooperation with USDA Forest Service, Rocky Mountain Region, Denver, CO.

Carrascal, L.M., J.A. Diaz, D.L. Huertas, and I. MozeTICH. 2001. Behavioral thermoregulation by treecreepers: trade-off between saving energy and reducing crypsis. Ecology 82:1642-1654.

Cochran W.G. 1977. Sampling techniques. 3rd edition. John Wiley \& Sons, Inc., New York. 428 pp.

Daubenmire, R. 1959. A canopy-coverage method of vegetational analysis. Northwest Science 33:43-64.

Dill, H.H., And W.H. Thornsberry. 1950. A cannonprojected net trap for capturing waterfowl. Journal of Wildlife Management 14:132-137.

[ESRI] Environmental Systems Research Institute. 1996. ArcView GIS software. Environmental Systems Research Institute, Redlands, CA.

FowElls, H.A. 1965. Silvics of forest trees of the United States: agriculture handbook 271. Division of Timber Management Research, USDA Forest Service, Washington, DC.

Gardner, D.T., AND D.H. ARnER. 1968. Food supplements and Wild Turkey reproduction. Transactions of the North American Wildlife and Natural Resources Conference 33:250-258.

Glazener, W.C., A.S. Jackson, And M.L. Cox. 1964. The Texas drop-net turkey trap. Journal of Wildlife Management 28:280-287.

Guthery, F.S., L.A. Brennan, M.J. Peterson, and J.J. LUSK. 2005. Information theory in wildlife science: critique and viewpoint. Journal of Wildlife Management 69:457-465.

Haroldson, K.J., M.R. Riggs, and R.O. Kimmel. 2001. Effects of cold on body temperature regulation of Wild Turkeys. Proceedings of the National Wild Turkey Symposium 8:61-67.

HengeL, D.A. 1990. Habitat use, diet and reproduction of Merriam's turkeys near Laramie Peak, Wyoming. Master's thesis, University of Wyoming, Laramie.

Hoffman, G.R., AND R.R. AleXander. 1987. Forest vegetation of the Black Hills National Forest of South Dakota and Wyoming: a habitat type classification. USDA Forest Service, Research Paper RM-276, Denver, CO.

Hoffman, R.W., H.G. Shaw, M.A. Rumble, B.F. WakeLing, C.M. Mollohan, S.D. Schemnitz, R. EngelWilson, and D.A. Hengel. 1993. Management guidelines for Merriam's Wild Turkeys. Colorado Division of Wildlife, Division Report Number 18, Fort Collins.

Hoffman, R.W., M.P. LutTRELl, and W.R. Davidson. 1996. Reproductive performance of Merriam's Wild Turkeys with suspected Mycoplasma infection. Proceedings of National Wild Turkey Symposium 7:145-151.

Hosmer, D.W., And S. Lemeshow. 2000. Applied logistic regression. 2nd edition. John Wiley \& Sons, Inc., New York. 392 pp.
JOHNSON, D.H. 1980. The comparison of usage and availability measurements for evaluating resource preference. Ecology 61:65-71.

Johnson, R.R., K.F. Higgins, And D.E. Hubbard. 1995. Using soils to delineate South Dakota physiographic regions. Great Plains Research 5:309-322.

KAISER, H.F. 1958. The varimax criterion for analytic rotation in factor analysis. Psychometrika 23:187-200.

Keating, K.A., and S. Cherry. 2004. Use and interpretation of logistic regression in habitat-selection studies. Journal of Wildlife Management 68:774-789.

Krugman S.L., and J.L. Jenkinson. 1974. Pinus L. In: C.S. Schopmeyer, technical coordinator, Seeds of woody plants in the United States. USDA Forest Service, Agriculture Handbook Number 450, Washington, DC.

Larson, G.E., And R.R. Johnson. 1999. Plants of the Black Hills and Bear Lodge Mountains: a field guide with color photographs. South Dakota State University, Brookings.

Lehman, C.P. 1998. A comparison of Eastern Wild Turkeys and Rio Grande Wild Turkeys in northeastern South Dakota. Master's thesis, South Dakota State University, Brookings.

. 2005. Ecology of Merriam's turkeys in the southern Black Hills, South Dakota. Doctoral dissertation, South Dakota State University, Brookings.

Manly, B.F.J., L.L. McDonald, and D.L. Thomas. 1993. Resource selection by animals: statistical design and analysis for field studies. Chapman and Hall, London. 177 pp.

Mielke, P.W., Jr., And K.J. Berry. 2001. Permutation methods: a discrete function approach. SpringerVerlag, New York. 352 pp.

Miller, R.G., JR. 1981. Simultaneous statistical inference. Springer-Verlag, New York. 299 pp.

National Climatic Data Center. 1971-2000. Climatological data, South Dakota, annual summary. National Oceanic and Atmospheric Administration, Asheville, NC.

Oliver, W.W., And R.A. Ryker. 1990. Silvics of North America. USDA Forest Service, Agriculture Handbook Number 654, Washington, DC.

Porter, W.F., R.D. Tangen, G.C. Nelson, and D.A. HamILTON. 1980. Effects of corn food plots on Wild Turkeys in the upper Mississippi Valley. Journal of Wildlife Management 47:281-290.

Porter, W.F., G.C. Nelson, AND K. Mattson. 1983. Effects of winter conditions on reproduction in a northern Wild Turkey population. Journal of Wildlife Management 47:281-290.

Robel, R.J., J.N. Briggs, A.D. Dayton, and L.C. HulBERT. 1970. Relationships between visual obstruction measurements and weight of grassland vegetation. Journal of Range Management 23:295-297.

Rogers, A.R., AND A.P. CARR. 1998. HRE: the home range extension for ArcView, user's manual. Centre for Northern Forest Ecosystems Research, Ontario Ministry of Natural Resources, Ontario, Canada.

Rumble, M.A., ANd S.H. Anderson. 1992. Stratification of habitats for identifying habitat selection by Merriam's turkeys. Great Basin Naturalist 52:139-144.

1993. Macrohabitat associations of Merriam's turkeys in the Black Hills, South Dakota. Northwest Science 67:238-245. 
1996a. Feeding ecology of Merriam's turkeys (Meleagris gallopavo merriami) in the Black Hills, South Dakota. American Midland Naturalist 136: 157-171.

1996b. Microhabitats of Merriam's turkeys in the Black Hills, South Dakota. Ecological Applications 6:326-334.

1996c. A test of the habitat suitability model for Merriam's Wild Turkeys. Proceedings of the National Wild Turkey Symposium 7:165-173.

SAS Institute. 2000. SAS/STAT user's guide, version 6 . 4th edition. SAS Institute, Cary, NC. 1686 pp.

Sharpe, G.W., C.W. Hendree, and S.W. Allen. 1976. Introduction to forestry. McGraw-Hill, New York. $544 \mathrm{pp}$.

Simmons, L. 1982. Photo series for quantifying forest residues in the Black Hills: ponderosa pine typespruce type. AFM 831, USDA Forest Service, Rocky Mountain Region, Fort Collins, CO.

StumpF, K.A. 1993. The estimation of forest vegetation cover descriptions using a vertical densitometer. Joint Inventory and Biometrics Working Groups Session, Indianapolis, IN.

Thompson, M.C., And R.L. Delong. 1967. The use of cannon and rocket projected nets for trapping shorebirds. Bird Banding 38:214-218.
Thompson, W.L. 1993. Ecology of Merriam's turkeys: in relation to burned and logged areas in southeastern Montana. Doctoral dissertation, Montana State University, Bozeman.

Vander Haegen, W.M., W.E. Dodge, and M.W. Sayre. 1988. Factors affecting productivity in a northern Wild Turkey population. Journal of Wildlife Management 52:127-133.

Wakeling, B.F., AND T.D. Rogers. 1995. Winter habitat relationships of Merriam's turkeys along the Mogollon Rim, Arizona. Arizona Game and Fish Department Technical Report Number 16, Phoenix.

. 1996. Winter diet and habitat selection by Merriam's turkeys in north-central Arizona. Proceedings of the National Wild Turkey Symposium 7:175-184.

Williams, L.E., JR. 1961. Notes on wing molt in the yearling Wild Turkey. Journal of Wildlife Management 25:439-440.

WunZ, G.A. 1984. Rocket-net innovations for capturing Wild Turkeys and waterfowl. Pennsylvania Game Commission, Pittman-Robertson Federal Aid Progress Report, Project W-46-R-21. Harrisburg, PA.

Received 4 January 2006 Accepted 11 September 2006 